\title{
Perspektywy przemian systemowych górnictwa i energetyki w świetle polityki klimatyczno-energetycznej Unii Europejskiej
}

The systemic changes in the coal mining and energy sectors from the perspective of the climate and energy policy of European Union

\section{Monika Morawiecka}

PGE Polska Grupa Energetyczna SA

Abstract

While assessing the scope of and pace of transition of coal-dependent regions one should not only focus on regulatory developments but to a much bigger extent on technological progress that enables substantial cost reduction of alternative energy sources. The transition has to also take into account macroeconomic and social impacts and choose the most rational path given geopolitical considerations. Jud-ging from other countries' experience, transition away from coal in electricity gene-rations takes decades rather than years, and should be managed in a way that does not compromise the security of supply and consumer cost issues.

Keywords - coal-fired generation, Polish power sector, fuel mix, renewables 


\section{Wstęp}

Dominujące w ostatnich latach podejście do oceny długoterminowych perspektyw polskiej polityki energetycznej opierało się w przeważającej mierze na analizie ograniczeń regulacyjnych, które były głównym wyznacznikiem myślenia o zmianach w polskim miksie energetycznym. W ostatnim okresie jednakże coraz bardziej staje się widoczny trend zmian technologicznych - a co za tym idzie, kosztów - w obszarze energetyki odnawialnej oraz magazynowania energii, a także postęp w uelastycznianiu systemów energetycznych, który wymusza rozszerzenie tej perspektywy i zweryfikowanie ustalonych dotychczas przekonań.

O ile w warunkach polskich trendy te były dotychczas stosunkowo mniej widoczne, to odpowiedzialne podejście do planowania przemian w sektorze energetycznym wymaga szerszego spojrzenia i korzystania z najnowszej dostępnej wiedzy - szczególnie w okresie tak dynamicznych zmian, jakie obserwujemy ostatnio.

\section{Paradygmat systemu energetycznego - czy potrzebujemy zmian?}

Tradycyjny „trójkąt energetyczny” oznaczający podstawowe cele, czy też ograniczenia, jakim musi podlegać system energetyczny, wydaje się być niezmienny. Nadal pierwszym i podstawowym dążeniem jest bezpieczeństwo energetyczne - czasami rozumiane wąsko - jako bieżące zaopatrzenie w energię, niezależnie od miejsca, z którego ta energia pochodzi - a coraz częściej szeroko - jako zapewnienie niezależności energetycznej. Przy czym to drugie podejście jest często prezentowane w różnej granulacji - jako niezależność gospodarstwa domowego (na razie dość złudna - bardzo duża liczba w pełni samowystarczalnych prosumentów to odległa przyszłość), gminy czy regionu, czy wreszcie - państwa.

Ta ostatnia definicja, w której bezpieczeństwo energetyczne oznacza niezależność, czy też suwerenność energetyczną kraju, wydaje się być podejściem preferowanym (choć niezbyt dobrze opisanym ${ }^{1)}$ w dokumentach programowych wyznaczających politykę

\footnotetext{
${ }^{1} \mathrm{~W}$ ustawie Prawo energetyczne definicja bezpieczeństwa energetycznego brzmi: „stan gospodarki umożliwiający pokrycie bieżącego i perspektywicznego zapotrzebowania odbiorców na paliwa i energię w sposób technicznie i ekonomicznie uzasadniony, przy zachowaniu wymagań ochrony środowiska". Można z tej definicji wywieść - choć niebezpośrednio, że chodzi tu o taki stan energetyki, w którym źródła wytwórcze, które mają dostarczać energię w przypadku kryzysu, znajdują się na terenie kraju.
} 
energetyczną Polski [1, 2]. Przy czym niezależność tę w sektorze elektroenergetycznym należy rozumieć nie jako zamknięcie się na możliwości importowe, ale jako zapewnienie możliwości zapewnienia dostaw energii ze źródeł krajowych w przypadku kryzysu. Innymi słowy, zapewnienie mocy rezerwowych, które mogą być uruchomione w przypadku, w którym import energii elektrycznej byłby niemożliwy (lub ekonomicznie nieopłacalny).

Dwa pozostałe wierzchołki trójkąta - zapewnienie przystępnej ceny oraz ochrona środowiska naturalnego - są niejako ograniczeniami narzuconymi na cel podstawowy, które wymuszają efektywność jego realizacji z punktu widzenia ekonomicznego oraz środowiskowego (przy czym podejście środowiskowe jest w istocie także ekonomicznym - w momencie kiedy uznajemy - a jest to zdecydowanie pogląd dominujący w całym cywilizowanym świecie - że szkody w środowisku należy kompensować, a negatywne efekty zdrowotne - kwantyfikować).

Należy w tym miejscu także nieco niuansować rozumienie terminu „przystępna cena”. Z reguły oznacza to cenę dla konsumenta końcowego, czy też - co jest lepszym wskaźnikiem - udział wydatków na energię w budżecie rozporządzalnym gospodarstwa domowego (w języku angielskim używany jest tu termin affordability, tłumaczony jako „dostępność”, dla którego cena jest tylko względna - gdyż musi być odniesiona do poziomu zamożności). Jednakże w wymiarze długoterminowym prawdopodobnie ważniejsze jest, czy cena energii elektrycznej jest dostępna dla przemysłu - i czy jej wzrost nie zaburza konkurencyjności tej gałęzi gospodarki. Polska jest relatywnie wysoko uprzemysłowionym krajem, w którym przemysł odpowiada za ok. 27\% PKB [3] i nie może pozwolić sobie na lekceważenie tego aspektu. Rozumieją to doskonale nasi zachodni sąsiedzi którzy od lat stosują politykę nakładania kosztów transformacji energetycznej na - zamożne przecież - gospodarstwa domowe, przy jednoczesnym znaczącym ograniczaniu wysokości tych obciążeń dla sektora przemysłowego.

Tak zdefiniowany paradygmat systemów energetycznych, mimo że nie jest niczym nowym, wymusza zdyscyplinowane podejście do oceny każdej decyzji wpływającej na te systemy. Podejście to oznacza każdorazowe zadawanie - i udzielanie skwantyfikowanych odpowiedzi na następujące pytania: Czy dane rozwiązanie przyczynia się do budowy bezpieczeństwa energetycznego (lub z innej strony: czy go nie osłabia)? Czy dane rozwiąznie nie wpływa w sposób nieuzasadniony na wzrost kosztów dla społeczeństwa? I czy dane rozwiązanie minimalizuje negatywny wpływ na środowisko? Należy tutaj zwrócić wyraźną uwagę, że o ile w pierwszych dwóch pytaniach mamy do czynienia z optymalizacją dwu- 
stronną - maksymalizacja korzyści bądź minimalizacją strat, to w przypadku oddziaływania na środowisko w zasadzie mówimy tylko o minimalizacji negatywnego oddziaływania - gdyż każda działalność człowieka ingeruje w środowisko naturalne.

\section{Rysunek 1. Paradygmat systemu energetycznego}

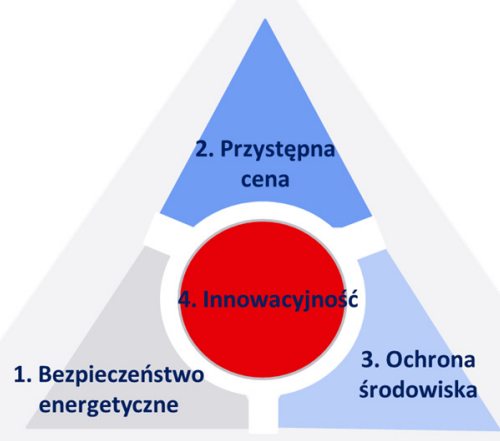

Źródło: Opracowanie własne.

Do tak zdefiniowanego „trójkąta energetycznego” dodano tutaj jeszcze jeden element, który nie jest ani celem samym w sobie, ani ograniczeniem, tylko środkiem do łatwiejszego, efektywniejszego osiagania celu czy też radzenia sobie z ograniczeniami (w języku angielskim adekwatny termin to enabler).

Innowacyjność, bo o niej tu mowa, staje się warunkiem koniecznym do efektywnego osiągania celów polityki energetycznej. I jest to innowacyjność z jednej strony rozumiana bardzo szeroko - jako innowacyjność nie tylko rozwiązań technicznych, ale także rynkowych, finansowych, modeli biznesowych czy regulacyjnych. Jest to także innowacyjność rozumiana jako nieustanne podnoszenie wiedzy na temat trendów technologicznych i odpowiednie reagowanie w ramach planowania polityki energetycznej. Jak zostanie to pokazane dalej, dotychczasowe przekonania czy niepodważalne prawdy muszą zostać obecnie zweryfikowane, a ta weryfikacja wymusi inne - innowacyjne - podejście do kształtowania systemu energetycznego.

Innowacyjność to wreszcie nieco inne podejście do horyzontu planowania. Z jednej strony istnieje tendencja do pokazywania bardzo długiej perspektywy czasowej dla systemów energetycznych - do 2050 roku i nawet dalej, a z drugiej - nowe technologie 
energetyczne mają z reguły dużo krótszy czas technologicznego i/lub ekonomicznego życia niż dawniej - co oznaczałoby konieczność planowania iteracyjnego, w częstszych cyklach, z wbudowaną elastycznością reagowania na zmiany pozwalającą uniknąć zbyt dużych kosztów osieroconych w przyszłości.

\section{Przyczynek do dyskusji o przyszłym miksie energetycznym}

Powyższe rozważania jak w soczewce skupiają się zawsze w dyskusjach o przyszłości polskiego miksu energetycznego. W chwili obecnej jeszcze ponad 80\% energii elektrycznej w Polsce jest wytwarzane z węgla - kamiennego i brunatnego. Wydaje się jednocześnie, że istnieje dość szeroki konsensus branżowy, iż udział ten w przyszłości będzie spadał. Dyskusja zatem przesunęła się z pytania „czy?”, na pytania „kiedy?” i ,jak?”. I tutaj już nie ma jednoznacznych odpowiedzi i bardzo trudno o uzgodnienie jednej wizji.

Jedna z możliwości rozwoju sektora energetycznego w przyszłości zaprezentowali pod koniec 2017 roku autorzy raportu zatytułowanego Mapa drogowa polskiej elektroenergetyki 2030+ [4]. Jest to interesujące opracowanie z kilku powodów - opiera się na najnowszej wiedzy dotyczącej istniejących i spodziewanych regulacji, uwzględnia trendy technologiczne i rynkowe oraz inne czynniki wpływające na wybór takich czy innych technologii wytwórczych, które są często bagatelizowane - jak np. czas przygotowania i realizacji danej inwestycji.

Wynikiem rozważań autorów raportu jest miks energetyczny, który po roku 2030 zakłada bardzo szybkie ograniczanie udziału węgla w wytwarzaniu energii elektrycznej na rzecz głównie paliwa gazowego oraz elektrowni wiatrowych na lądzie i na morzu.

Nie wchodząc zbyt głęboko w dyskusję z autorami raportu co do szczegółów takiej wizji i co do jej wykonalności w prezentowanym horyzoncie czasowym (w tym co do realności założenia o spadającej konsumpcji energii elektrycznej po roku 2030 - co z uwagi na planowaną elektryfikację transportu może okazać się być założeniem błędnym), warto podsumować w skrócie argumenty, które skłoniły autorów do przedstawienia jako prawdopodobnego powyższego scenariusza. Należy bowiem wyraźnie podkreślić, iż w dyskusjach o rozwoju sektora energetycznego w tak długim horyzoncie czasowym zawsze powinniśmy rozmawiać o scenariuszach, a nie o jednej zdeterminowanej i niepodważalnej przyszłości. 
Rysunek 2. Prognozowany w raporcie Mapa drogowa polskiej elektroenergetyki 2030+ miks energetyczny w Polsce do roku 2040, TWh

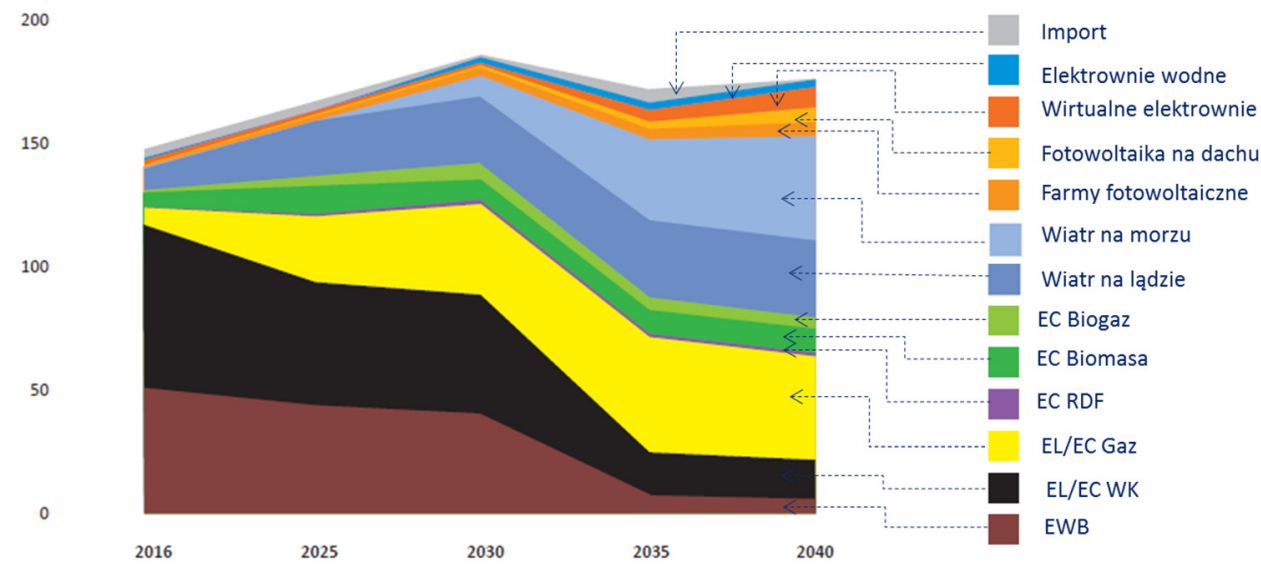

Źródło: [4].

Oczywiście część podejmowanych już teraz, czy w przeciagu kilku następnych lat, decyzji zdeterminuje częściowo przyszłość na najbliższych kilkanaście czy nawet kilkadziesiąt lat - chociażby decyzje o trwałych wyłączeniach jednostek, czy też o budowie nowych. Natomiast cały czas pozostanie jeszcze sfera „niezagospodarowana”, co do której decyzje będą podejmowane za jakiś czas i nie można z cała pewnością dziś przewidzieć w jakich uwarunkowaniach makroekonomiczno-regulacyjno-technologicznych. Dodatkowo, historia systemów energetycznych zna wiele przypadków generowania tzw. „kosztów osieroconych”, czyli inwestycji, które nie uzyskały wymaganej użyteczności ekonomicznej poprzez wcześniejsze zaprzestanie eksploatacji czy też ograniczenie czasu pracy.

Warto zatem przyjrzeć się choćby pobieżnie, argumentom, które stały za zaprezentowanymi na powyższym rysunku głównymi trendami kształtującymi przewidywany przez autorów raportu miks energetyczny.

Najbardziej rzucającym się w oczy i jednocześnie stojącym w sprzeczności z zapowiedziami przedstawicieli Ministerstwa Energii jest znaczący spadek wykorzystania węgla kamiennego i brunatnego w horyzoncie prognozy. Głównym argumentem jest tutaj oczywiście kontynuacja polityki energetyczno-klimatycznej Unii Europejskiej. Polityka ta podnosi koszty generacji energii w elektrowniach węglowych poprzez dwa główne 
instrumenty - ceny uprawnień do emisji $\mathrm{CO}_{2}$ oraz kolejne regulacje środowiskowe wymuszające kosztowne modernizacje. Od jakiegoś czasu do tych dwóch elementów dochodzą także planowane regulacje jeszcze bardziej bezpośrednio ingerujące w możliwość generowania satysfakcjonujących wyników przez elektrownie węglowe, jak procedowana obecnie w ramach negocjacji tzw. „pakietu zimowego”2 regulacja ustanawiająca zakaz udziału elektrowni węglowych w mechanizmach mocowych [6].

Rysunek 3. Cena uprawnień do emisji CO2 w okresie maj 2017 - maj 2018

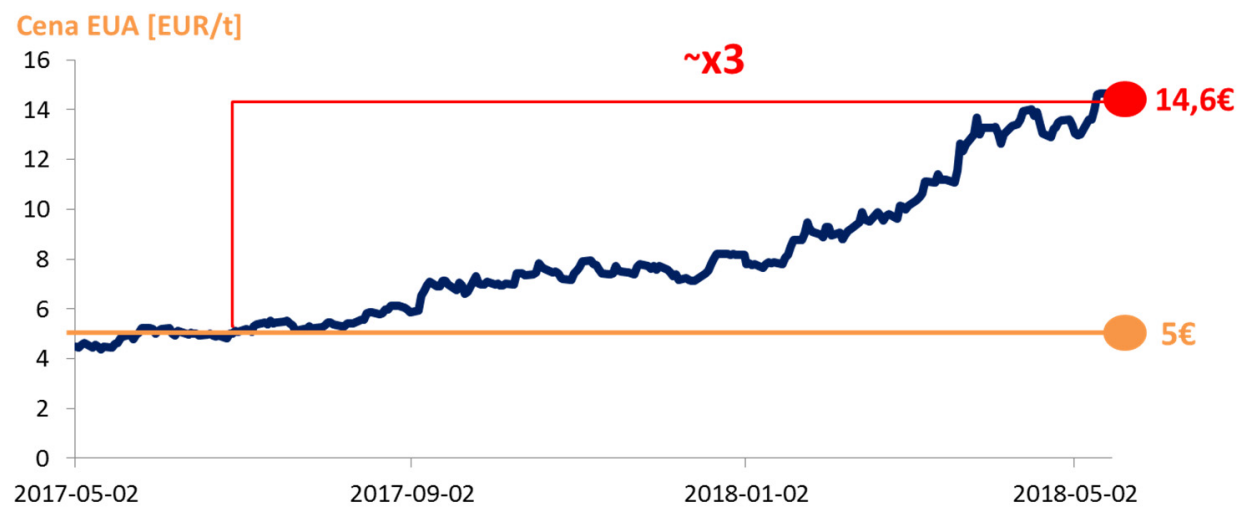

Źródło: Opracowanie własne.

Nie wydaje się przy tym, żeby ta polityka penalizująca źródła wysokoemisyjne miała się w przewidywalnym czasie znacząco zmienić. Należy raczej oczekiwać, szczególnie w kontekście toczącego się procesu wdrażania porozumienia paryskiego w ramach UNFCC [7], podnoszenia ambicji unijnych w zakresie redukcji emisji $\mathrm{CO}_{2}$ i wprowadzania kolejnych mechanizmów tę redukcję wymuszających, czy ekonomicznie czy też administracyjnie. Widać to w szczególności w toczącej się cały czas debacie o cenach uprawnień do emisji $\mathrm{CO}_{2}$, w której mimo ogromnego wzrostu w ciąu ostatniego roku, pojawiają się silne głosy o potrzebie kolejnej „reformy” systemu EU ETS w celu zapobieżenia spodziewanej stabilizacji tej ceny w ciagu kilku następnych lat.

\footnotetext{
2 Pakiet legislacyjny Unii Europejskiej pod nazwa „Czysta energia dla wszystkich Europejczyków”, zaprezentowany przez Komisję Europejską w listopadzie 2016 roku, nad którym prace mogą zostać sfinalizowane do końca 2018 roku lub na początku 2019 roku [5].
} 
Rysunek 4. Prognozy cen uprawnień do emisji $\mathrm{CO}_{2}$ do 2030 roku

\begin{tabular}{llllll} 
& $\mathbf{2 0 1 8}$ & $\mathbf{2 0 1 9}$ & $\mathbf{2 0 2 0}$ & $\mathbf{2 0 2 5}$ & $\mathbf{2 0 3 0}$ \\
\hline Energy Aspects & 15,5 & 20,4 & 24,7 & 21,0 & 36,0 \\
\hline JP Morgan & 10,0 & 15,0 & 20,0 & 25,0 & 25,0 \\
\hline Nomisma Energia & 11,2 & 15,8 & 16,2 & bd & 28,0 \\
\hline Engie Global Markets & 12,0 & 12,5 & 15,0 & bd & bd \\
\hline ICIS dla Eurelectric & nd & nd & 15,0 & 30,0 & 25 \\
\hline Średnia & $\mathbf{1 2 , 2}$ & 15,9 & $\mathbf{1 8 , 2}$ & $\mathbf{2 5 , 3}$ & $\mathbf{2 8 , 5}$ \\
\hline
\end{tabular}

Źródło: Opracowanie własne na podstawie danych KOBIZE [8].

Drugim ważnym aspektem, na jaki zwracają uwage autorzy raportu, jest ograniczony potencjał górnictwa węgla kamiennego w Polsce. Są to wyczerpujące się zasoby oraz warunki geologiczne w istniejących kopalniach z jednej strony, a z drugiej strony trudność w planowaniu zagospodarowywania złóż perspektywicznych ze względu na uwarunkowania środowiskowe i społeczne.

Powyższe aspekty sprawiają iż w obszarze „,tradycyjnej” energetyki, relatywną przewagę kosztową wg autorów raportu zaczynają zdobywać źródła gazowe - które z jednej strony są bardziej dostosowane do wymogów przyszłych systemów energetycznych z większym udziałem niesterowalnych odnawialnych źródeł energii (OZE), a z drugiej są znacznie mniej obciążające dla środowiska. Źródła gazowe mają również duży potencjał w rozwoju ciepłownictwa, które także ma takie same wyzwania jeśli chodzi o wymogi środowiskowe jak sektor elektroenergetyczny. Przy prowadzonej dywersyfikacji kierunków dostaw gazu do Polski stają się także akceptowalne politycznie.

Uwzględniony przez autorów raportu znaczący wzrost udziału OZE wynika przede wszystkim z obecnych i przewidywanych kosztów tych technologii, o czym szerzej w punkcie 4 poniżej. Natomiast brak energii jądrowej w prezentowanym miksie do roku 2040 tłumaczony jest faktem, iż zaplanowane w Programie Polskiej Energetyki Jądrowej wdrożenie technologii III generacji nie powiedzie się na czas, w którym nowe moce będą potrzebne po wycofaniu z eksploatacji części bloków węglowych. Autorzy raportu oszacowali bowiem czas przygotowania i budowy elektrowni jądrowej na ok. 18 lat (za KPRM [10]). 
Oznacza to, że w tym czasie trzeba będzie uzupełnić moce wytwórcze innymi źródłami - głównie OZE i gazowymi, co na jakiś czas (a przynajmniej w horyzoncie prognozy raportu) sprawi, iż budowa mocy jądrowych nie będzie potrzebna. Dodatkowymi argumentami podnoszonymi przez autorów raportu są bardzo wysokie i trudne obecnie do dokładnego oszacowania koszty inwestycyjne technologii jądrowych, a także wymuszana przez nie specyfika pracy tych elektrowni (tzw. praca w podstawie systemu). Nie jest ona optymalna z punktu widzenia wymagań stawianych przed systemem energetycznym w świetle rosnącego udziału OZE oraz regulacji pakietu zimowego, preferujacych elektrownie mogace elastycznie reagować na dobowe zmiany zapotrzebowania ${ }^{3}$.

Jeśli chodzi o długość trwania procesów inwestycyjnym w sektorze energetycznym ogółem, konieczna jest dodatkowa uwaga. Wg raportu Climbing the curve. 2015 Global Construction Project Owner's Survey [11] ponad 50\% projektów inwestycyjnych ogółem, a ponad $70 \% \mathrm{w}$ energetyce, realizowanych jest niezgodnie $z$ założonym pierwotnie harmonogramem lub budżetem. Na ,normalne” wyzwania związane z prowadzeniem dużych projektów, jak procesy środowiskowe czy planistyczne, w energetyce europejskiej nakładają się dodatkowo bardzo skomplikowane kwestie finansowania, często związane z koniecznością wypracowania (i notyfikowania w Komisji Europejskiej!) adekwatnych systemów wsparcia. Ten aspekt w żadnej mierze nie może być pomijany w rozważaniach na temat przyszłego miksu energetycznego.

\section{Ograniczanie znaczenia węgla w energetyce - skutki społeczno-gospodarcze}

Z przytoczonymi dość pobieżnie założeniami, które skłoniły autorów opisywanego raportu do zaprezentowania powyższej prognozy miksu energetycznego z pewnością można, a wręcz należy podjać krytyczną dyskusję. Wydaje się jednak, że przedstawiony w raporcie podstawowy kierunek, jakim jest ograniczanie roli węgla, nie powinien być kontestowany. Elektrownie węglowe, obciążane kolejnymi kosztami środowiskowymi, o dość długim czasie przygotowania i budowy, sporych kosztach kapitałowych oraz paliwowych nie sprostają konkurencji z taniejącymi źródłami odnawialnymi. Z całą pewnością

\footnotetext{
${ }^{3}$ Ang. load following. Problem ten nie tyle jest natury technicznej (istnieją dane wskazujące na dość dobrą pracę elektrowni jądrowych przy zmiennym obciazzeniu, np. we Francji), co ekonomicznej. Przy bardzo wysokich nakładach inwestycyjnych na elektrownię jądrową musi ona pracować z maksymalną możliwą moca, aby uzyskać satysfakcjonujący inwestora poziom rentowności.
} 
rodzić to będzie jednak problemy w obszarze społeczno-gospodarczym na poziomie regionalnym, a także dla samego systemu energetycznego na poziomie krajowym.

Z punktu widzenia makroekonomicznego, jeśli spojrzymy na województwo śląskie, górnictwo węgla kamiennego stanowi nadal istotny, choć malejący element gospodarki regionu 4 . Podczas gdy w 2005 roku udział górnictwa w produkcji sprzedanej przemysłu stanowił ponad 15\%, w 2016 roku było to już tylko nieco ponad $9 \%$ - niewiele więcej niż sektor produkcji artykułów spożywczych i napojów (8,3\%), i ponad trzykrotnie mniej niż sektor motoryzacyjny (28,3\%) [12].

Inaczej jest jednak jeśli spojrzeć na poziom zatrudnienia. Z ponad 80 tysiącami zatrudnionych sektor górnictwa jest największym pracodawcą wśród śląskich sektorów przemysłowych (choć zauważyć należy, że przemysł motoryzacyjny jest na drugim miejscu, zwiększając zatrudnienie pomiędzy 2005 a 2016 rokiem z niecałych 30 tys. do niemal 60 tys. osób - przy czym ze znacznie niższym średnim wynagrodzeniem). Stopa bezrobocia województwa śląskiego w roku 2016 wyniosła natomiast 5,4\% (spadek z 9,1\% w 2010 roku) [12].

$\mathrm{Na}$ pierwszy rzut oka z zaprezentowanych powyżej uproszczonych danych ${ }^{5}$ można wysnuć wniosek, że dobrze zaplanowana, rozłożona na długi okres i wsparta odpowiednimi środkami finansowymi transformacja regionu śląskiego w kierunku zastapienia górnictwa innymi sektorami gospodarki może stać się dobrym kierunkiem rozwoju. Jeśli chodzi zaś o samą energetykę, to jak wspomniano w punkcie 2 powyżej, przy odpowiednio wczesnym przygotowaniu procesów inwestycyjnych od strony regulacyjnej i finansowej, nie powinno być problemu z zastąpieniem wycofywanych stopniowo z użytku mocy węglowych.

Pouczający jest tu przykład Wielkiej Brytanii, która kończy przechodzić proces odejścia od energetyki węglowej, rozpoczęty w latach 50. zeszłego wieku. Proces ten rozpoczął się od wprowadzenia pod koniec lat 50. najpierw ropy naftowej (która po szokach naftowych straciła zupełnie na znaczeniu do połowy lat 90.) a następnie energetyki jądrowej. Kolejną dużą zmianą była budowa w latach 90. XX wieku i na początku XXI na wielką skalę elektrowni gazowych (zasilanych z własnych złóż gazu

\footnotetext{
${ }^{4}$ Nie jest tu rozważany sektor energetyczny, gdyż przyjmuje się upraszczające założenie, że wycofywane z użycia elektrownie węglowe będą zastępowane przez inne źródła wytwórcze, a ewentualna różnica w zatrudnieniu nie będzie znacząca.

${ }^{5}$ Dane te nie obejmują sektorów powiązanych, jak produkcja maszyn górniczych itp.
} 
z Morza Północnego), a w ostatnich latach widać bardzo duży skok źródeł odnawialnych (obecnie stanowią już prawie 30\% w miksie energetycznym). Całkowity koniec zużycia węgla w energetyce jest planowany do roku 2025.

Rysunek 5. Zmiany miksu energetycznego w Wielkiej Brytanii, 1920-2025

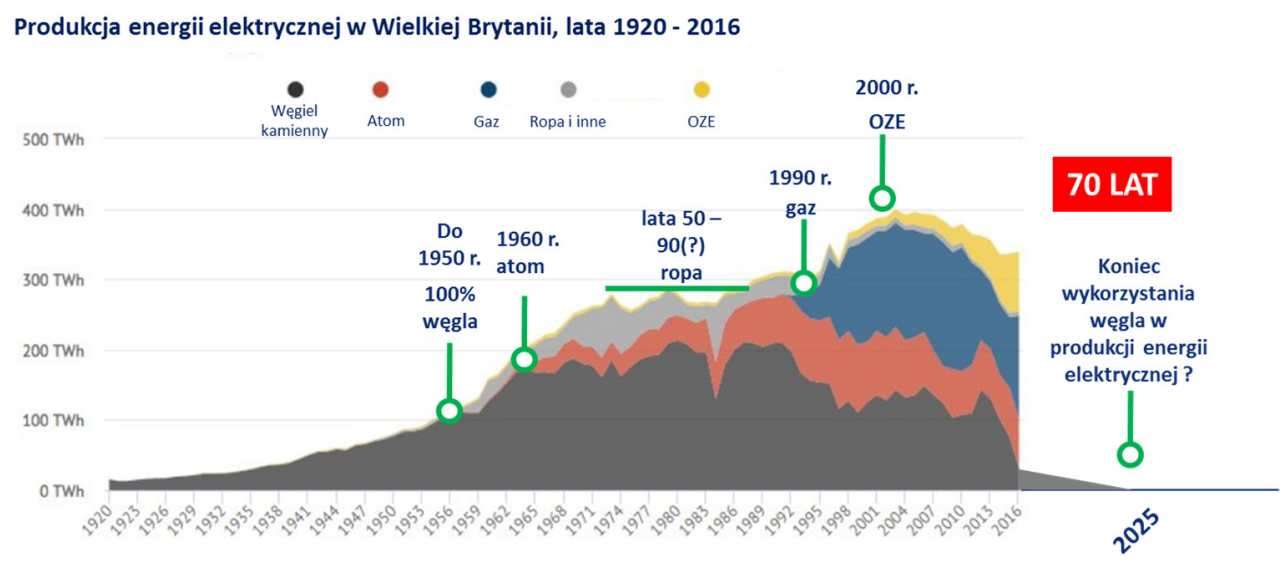

Źródło: Opracowanie własne.

Rozwój OZE jest przy tym zaplanowany łącznie z dość skuteczną strategią przemysłową, szczególnie w obszarze morskiej energetyki wiatrowej, która w ostatnich latach bardzo zyskuje na znaczeniu. Rząd brytyjski wymaga, żeby inwestorzy w morskie farmy wiatrowe przedstawili plan łańcucha dostaw i ocenia go pod kątem tzw. poziomu local content, czyli udziału rodzimego przemysłu i usług. Poziom ten obecnie osiagany jest już w wysokości ok. 50\% - co przy dość kapitałochłonnych inwestycjach, jakimi są farmy wiatrowe na morzu, stanowi dość duży impuls gospodarczy dla regionów nadmorskich, przy których są instalowane.

\section{Odnawialne źródła energii - początek prawdziwej rewolucji?}

Perspektywy rozwoju energetyki odnawialnej wymagają trochę bliższego przyjrzenia się. Proponenci tych źródeł wytwórczych od lat bardzo silnie promują taki sposób wytwarzania energii, z reguły podkreślając jego korzyści, a często całkowicie pomijając wady. 
Wśród tych wad dotychczas najczęściej (i słusznie!) powtarzane były wysokie koszty tych technologii.

I rzeczywiście, niewatpliwe zalety wytwarzania energii elektrycznej w źródłach wiatrowych czy słonecznych przy niemal zerowych kosztach zmiennych, po wykonaniu pełnego rachunku ekonomicznego uwzględniającego dość wysokie nakłady inwestycyjne i stosunkową małą produktywność mocno traciły na znaczeniu wśród osób, które ograniczenie kosztowe w paradygmacie energetycznym traktowały poważnie.

Nie można jednak nie zauważyć prawdziwego postępu, jaki dokonał się w tym obszarze w ostatnich kilku latach. Dla prześledzenia tego procesu najlepiej jest posłużyć się z kolei doświadczeniem niemieckim, które także od lat jest przedstawiane, szczególnie w Polsce, jako przykład błędnych i kosztownych decyzji.

W roku 2016 całkowity koszt systemu wsparcia OZE w Niemczech wyniósł 23 mld EUR, a tzw. opłata OZE (niem. EEG-Umlage) stanowiła 22\% rachunku za energię elektryczną przeciętnego gospodarstwa domowego [13]. Liczb tych nie należy jednak traktować jako wyznacznika obecnych (a tym bardziej przyszłych) kosztów budowy źródeł odnawialnych. Niemcy wprowadzili bardzo hojny system wsparcia OZE (wysokie taryfy gwarantowane) już w roku 2000, a największy rozwój tych źródeł (w szczególności najdroższej ówcześnie fotowoltaiki) przypadł na lata 2009-2012.

\section{Rysunek 6. Zmiany w wysokości wsparcia dla instalacji fotowoltaicznych i wiatrowych w Niemczech}
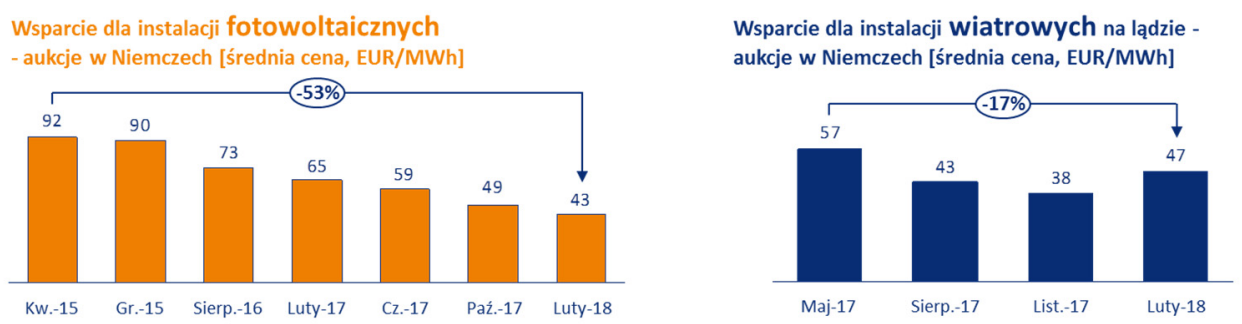

Źródło: Opracowanie własne na podstawie danych Bundesnetzagentur [13].

Niemiecka ustawa o odnawialnych źródłach energii podlegała w tym czasie wielokrotnym zmianom, w szczególności po okresie intensywnego rozwoju OZE, kiedy obciążenia dla odbiorców zaczęły rosnąć w tempie niekontrolowanym. Zmiany te miały na celu dopasowywanie wysokości wsparcia do spadających już dość dynamicznie w owym 
czasie kosztów wytworzenia energii ze źródeł odnawialnych. Ostatnie reformy ustawy wprowadziły całkowitą zmianę systemu wsparcia - od taryf gwarantowanych do systemu aukcyjnego, wymuszającego na inwestorach konkurencję o ograniczoną pulę mocy. Efekty tej zmiany możemy obserwować m.in. od dwóch lat dla fotowoltaiki i od roku dla wiatru na lądzie.

Nie zagłębiając się w szczegółową analizę powyższych danych można z całą pewnością stwierdzić, że obecnie instalowane elektrownie fotowoltaiczne oraz wiatrowe zbliżają się kosztami produkcji energii elektrycznej do hurtowej ceny energii w Europie. Oznacza to, że w nieodległej przyszłości możemy być świadkami prawdziwej rewolucji w sektorze energetycznym, która jeszcze kilka lat temu wydawała się być futurologia, czyli rozwoju źródeł odnawialnych bez systemów wsparcia ${ }^{6}$.

Rysunek 7. Hurtowa cena energii na wybranych rynkach europejskich, EUR/MWh

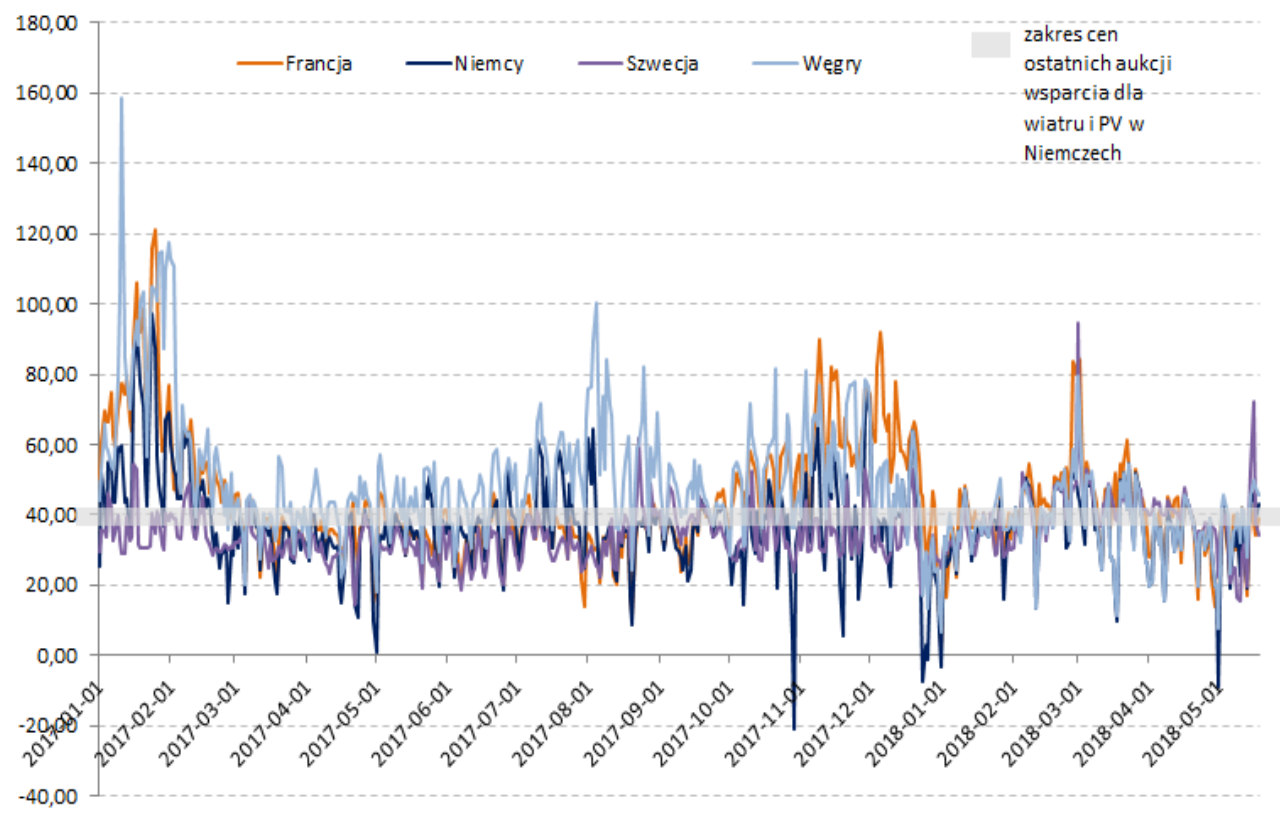

Źródło: Opracowanie własne.

\footnotetext{
${ }^{6}$ Pierwsze projekty budowane bez wsparcia już się pojawiaja - oparte o długoterminowe kontrakty z przemysłowymi odbiorcami energii.
} 
Oczywiście sama wysokość wsparcia dla źródeł odnawialnych nie jest jedynym czynnikiem kosztowym dla systemu energetycznego wynikającego z ich budowy. Ważne sa też koszty integracji tych źródeł z systemem wynikające z ich niesterowalnego charakteru pracy. Te koszty w Niemczech obecnie wynoszą ponad 1 mld EUR rocznie. Kwestia ta jest obecnie przedmiotem wielu studiów i badań - czyli jak zmniejszyć całkowite koszty systemu przy dużym udziale źródeł odnawialnych. Z całą pewnością nie ma prostej odpowiedzi na to pytanie, jeśli rozważamy bardzo wysokie udziały OZE w systemie (zapewne powyżej 50\%). Jeśli natomiast poruszamy się w niższych zakresach, wydaje się, że kwestia ta jest do (kosztowo efektywnego) rozwiązania na gruncie już obecnie dostępnych technologii.

W szczególności, system energetyczny wymagać będzie w takim przypadku uelastycznienia w bardzo wielu aspektach:

- $\quad$ Podażowym - poprzez uelastycznienie istniejących i budowę nowych źródeł wytwórczych, będących dostosowanych (technicznie i ekonomicznie!) do pracy w zmiennym obciążeniu, z wieloma uruchomieniami i odstawieniami; w obszarze podażowym mieszczą się także np. magazyny ciepła, które pozwola na elastyczną pracę elektrociepłowni nie tylko latem, ale i zimą.

- $\quad$ Popytowym - poprzez wykorzystanie potencjału zarządzania strona popytowa, czy też lepiej - poprzez umożliwienie optymalnego udziału strony popytowej w rynku energii.

- $\quad$ Rynkowym - poprzez reformę rynku w kierunku lepszego generowania sygnałów cenowych oraz właściwej wyceny świadczonych przez różnych jego uczestników usług.

- $\quad$ Sieciowym - poprzez elastyczne zarządzanie siecią przesyłową i dystrybucyjna (także dzięki tzw. technologiom smart grid) oraz optymalne wykorzystanie interkonektorów.

- Magazynowania energii - poprzez stworzenie odpowiednich zachęt rynkowych do wykorzystania istniejacych magazynów (elektrownie szczytowopompowe) oraz budowy nowych, tam gdzie to będzie ekonomicznie uzasadnione (m.in. magazyny bateryjne). 


\section{Uwagi końcowe}

Główną konkluzja, jaka się nasuwa po nawet tak pobieżnej analizie uwarunkowań, jakim podlega planowanie przemian w sektorze górnictwa i energetyki w Polsce, jest to, że należy przede wszystkim rozpatrywać te przemiany w szerokiej perspektywie, przy uwzględnieniu najnowszej wiedzy technologicznej, rynkowej, ekonomicznej i regulacyjnej. Przemiany w energetyce nie zachodzą w tak szybkim tempie, jak choćby w technologiach komunikacyjnych, ale w wystarczająco szybkim, żeby wymuszać gruntowną weryfikację konkluzji i przekonań sprzed kilku zaledwie lat.

Czy zatem to jeszcze regulacje, czy może już technologie będą wyznaczać przyszły kształt polskiej energetyki? Czy rozwój OZE jest złem koniecznym, czy może pożądanym elementem miksu, jeśli przyjmiemy, że może być (już jest?) kosztowo efektywny, społecznie akceptowalny, podlegający kontroli i generujący dużą wartość dodaną dla gospodarki? Czy elektrownie gazowe z uwagi na swój relatywnie krótki czas realizacji oraz relatywnie małe nakłady inwestycyjne nie są najlepszym źródłem do zabezpieczenia rezerwy w systemie (przy założeniu dywersyfikacji kierunków dostaw oraz odpowiedniego rozwoju infrastruktury gazowej)? Czy strategia gospodarcza kraju jest w stanie zaproponować odpowiednie programy rozwojowe dla regionów, które w przyszłości stracą część swoich obecnych sektorów przemysłowych?

$\mathrm{Na}$ takie pytania należy sobie odpowiedzieć dla odpowiedzialnego podejścia do planowania przyszłości polskiej energetyki. Należy mieć nadzieję, że szeroka debata środowiska naukowego, przemysłu oraz sfery politycznej doprowadzi do racjonalnych konkluzji w tym zakresie.

\section{Literatura}

[1] Ustawa z dnia 10 kwietnia 1997 r. - Prawo energetyczne (1997), Dz.U. Nr 54, poz. 348

[2] Polityka energetyczna Polski do 2030 roku (2010), „Monitor Polski” nr 2, poz. 11

[3] Rocznik statystyczny Rzecsypospolitej Polskiej 2017 (2017), GUS, Warszawa 
[4] Mapa drogowa polskiej elektroenergetyki 2030+ (2017), (red.) Schnell Ch., Instytut Jagielloński, Warszawa, http://jagiellonski.pl/wp-content/uploads/2018/05/rapo rt.pdf [17.05.2018]

[5] Communication from the Commission to the European Parliament, the Council, the European Economic and Social Committee, the committee of the Regions and the European Investment Bank Clean Energy For All European (2016), COM/2016/0860, http://eur-lex.europa.eu/legal-content/EN/ALL/?uri=CE LEX:52016DC0860 [17.05.2017]

[6] Proposal for a Regulation of the European Parliament and of the Council on the internal market for electricity (recast) (2016), 2016/0379/COD, https://eurlex.europa.eu/procedure/EN/2016_379 [17.05.2018]

[7] Paris Agreement (2015), https://unfccc.int/files/meetings/paris_nov_2015/application/pdf/paris_agreement_english_.pdf [17.05.2018]

[8] Raport z rynku $\mathrm{CO}_{2}$ (2018), KOBiZE nr 73, http://www.kobize.pl/uploads/materialy/materialy_do_pobrania/raport_co2/2018/Raport_z_rynku_CO2_kwiecien_2018.pdf [17.05.2018]

[9] Uchwała nr 15/2014 Rady Ministrów z dnia 28 stycznia 2014 r. w sprawie programu wieloletniego pod nazwą „Program polskiej energetyki jądrowej” (2014), M.P. 2014, poz. 502

[10] Model optymalnego miksu energetycznego dla Polski do roku 2060 (2015), Raport, Kancelaria Prezesa Rady Ministrów, https://www.premier.gov.pl/files/files/energymix_das_1.pdf [18.05.2018]

[11] Climbing the curve. 2015 Global Construction Project Owner's Survey (2015), KPMG International, https://assets.kpmg.com/content/dam/kpmg/pdf/2015/04/glo bal-construction-survey-2015.pdf [18.05.2018]

[12] Rocznik statystyczny wojewódžtwa ślaskiego 2017 (2017), Urząd Statystyczny w Katowicach, Katowice

[13] Energie-Info: Erneuerbare Energien und das EEG: Zablen, Fakten, Grafiken (2017), Bundesverband der Energie- und Wasserwirtschaft e.V. (BDEW), Berlin, https://www.bdew.de/media/documents/Awh_20170710_Erneuerbare-Energien-EEG_2017.pdf [18.05.2018] 